\title{
EFFECTS OF TREE COVER ON PARKING LOT MICROCLIMATE AND VEHICLE EMISSIONS
}

\author{
by Klaus I. Scott, James R. Simpson, and E. Gregory McPherson
}

\begin{abstract}
A pilot study was performed to measure the difference in parking lot microclimate resulting from the presence or absence of shade tree cover. Microclimate data from contrasting shade regimes were then used as input to a motor-vehicle emissions model. Model results were used to estimate the potential for regional increases in parking lot tree cover to reduce motor-vehicle hydrocarbon and nitrogen oxide (NOx) emissions.
\end{abstract}

Key Words. Parking lot; microclimate; vehicle emissions.

In the United States, approximately 200,000 shade trees were planted annually between 1992 and 1996 as a means to mitigate heat islands, protect climate, and improve air quality in urban areas (ICLEI 1997). Like many urban areas of the United States, Sacramento, California, has summertime episodes where ozone concentrations violate the federal air-quality standard. Ozone is formed through atmospheric photochemical reactions involving precursors such as oxides of nitrogen (NOx) and hydrocarbons in the form of "reactive organic gases" (ROGs). To reduce the ozone problem, air-quality agencies seek to reduce NOx and ROG emissions from stationary (industrial), area (dispersed sources such as small businesses, consumer products), and mobile (vehicles) sources within the metropolitan area. In Sacramento, where motor vehicles are major sources of NOx (68\%) and ROGs (49\%), current countywide emissions of NOx and ROGs from all sources are 86 and 120 tons per day (tpd, 1.102 tons $=1$ metric ton), respectively (ARB 1995a). On-road motor-vehicle NOx and ROG emissions are, on an annual average basis, approximately 59 tpd each (ARB 1995a).

While the bulk of vehicle ROG emissions are in the form of tailpipe exhaust, approximately $9.7 \mathrm{tpd}$ $(16 \%)$ are in the form of evaporative emissions when vehicles are not operating. "Diurnal" emissions occur during daytime heating of fuel delivery systems. "Resting loss" emissions occur during periods of constant or decreasing air temperature. "Hot soak" emis- sions occur during the hour following engine shutdown. "Start" emissions occur during the first few minutes of engine operation and are dependent on both ambient temperature and the duration that an engine is off prior to a start. Diurnal, resting loss, hot soak, and start emissions are sensitive to local air temperatures, which are influenced by local meteorological and microclimate conditions. These types of emissions may therefore be more severe in locations where vehicles are concentrated and where temperatures are high, such as unshaded parking lots.

Parking lots can be characterized as miniature heat islands and sources of motor-vehicle pollutants (Hahn and Pfeifer 1994; Asaeda et al. 1996). Through cooling of heat islands, urban forests may reduce vehicle hydrocarbon emissions (Cardelino and Chameides 1990; Taha 1996, 1997). Vegetation canopies cool microclimates by direct shading of the ground surface and indirectly by the transpiration of water through leaves (Lee 1978; Oke 1987). Airtemperature differences of approximately $2^{\circ} \mathrm{C}$ to $4^{\circ} \mathrm{C}$ $\left(3.6^{\circ} \mathrm{F}\right.$ to $7.2^{\circ} \mathrm{F}$ ) have been observed for urban neighborhoods of contrasting tree cover, averaging approximately $1^{\circ} \mathrm{C}\left(1.8^{\circ} \mathrm{F}\right)$ per $10 \%$ canopy cover (Huang et al. 1987; Myrup et al. 1993; Simpson et al. 1994). In Sacramento, temperature differences of $5^{\circ} \mathrm{C}$ to $7^{\circ} \mathrm{C}\left(9^{\circ} \mathrm{F}\right.$ to $\left.12.6^{\circ} \mathrm{F}\right)$ have been observed between tree-shaded suburban and unirrigated grassland rural surroundings (Grimmond et al. 1993). "Oasis effects" measured at an isolated orchard in Davis, California, resulted in air-temperature reductions of $4.5^{\circ} \mathrm{C}\left(8.1^{\circ} \mathrm{F}\right)$ within $5 \mathrm{~m}(16.4 \mathrm{ft})$ of an upwind edge (Taha et al. 1991).

The shading and cooling potential of parking lot tree plantings is determined by a host of factors including species composition, size, growth, crown density, spatial arrangement, and water use (Beatty 1989; NADF 1995). Though many western U.S. municipal ordinances require that parking lots be designed to provide $50 \%$ shade, our observations suggest that few lots attain this goal. Preliminary 
field surveys conducted by Forest Service researchers in Davis indicated a wide variability in parking lot canopy cover, ranging from $8 \%$ to $45 \%$ and averaging 25\% (Wong 1996). Together, these findings suggest that with proper design and management, reasonable increases in canopy cover and shade may achieve air-temperature reductions and reduced emissions from parked vehicles.

\section{OBJECTIVES}

Using measured temperature data and a vehicle emissions model, we performed a pilot study to estimate the potential of parking lot shade trees to reduce regional vehicle hydrocarbon emissions. Coincident climate data from both a conventional meteorological monitoring site and a parking lot were monitored to address differences between 1) conventional meteorological monitoring site and parking lot climate (especially air temperature), 2) shaded and unshaded parking lot air temperature, and 3) shaded and unshaded vehicle temperature.

\section{METHODS}

To estimate potential vehicle emission reductions due to tree shade, observed parking lot air-temperature regimes were used to design "base case" and "treatment" scenarios to represent regional hypothetical increases in parking lot canopy cover. To quantify vehicle emissions for different amounts of

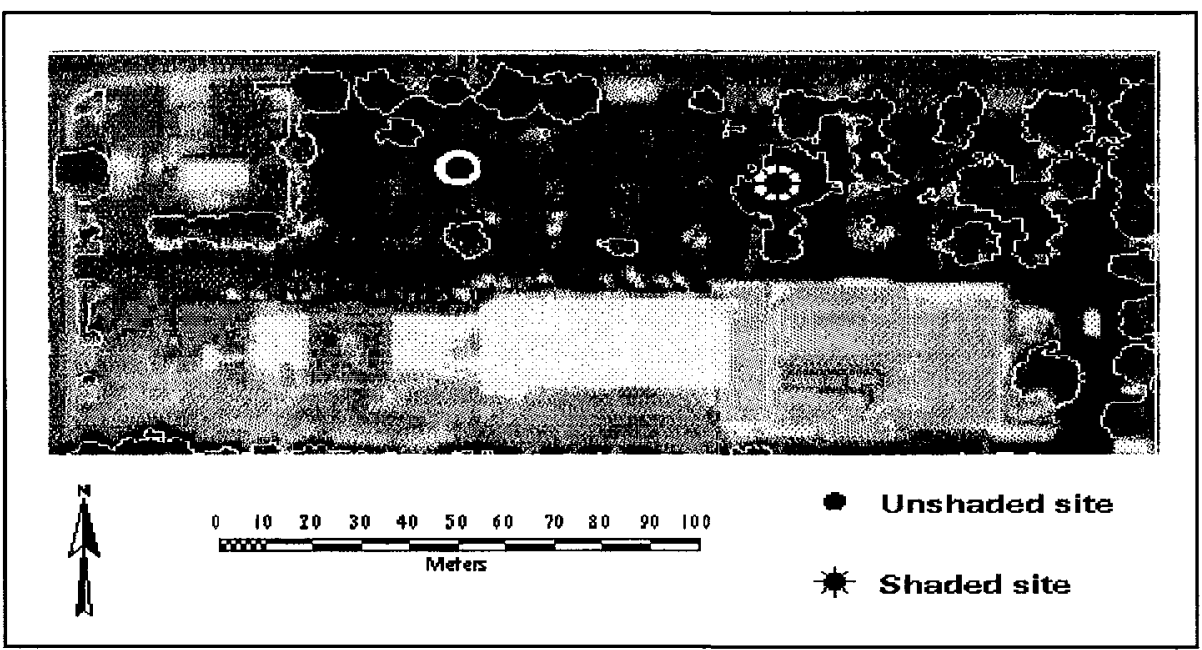

Figure 1. Aerial photo of parking lot. Shaded parking lot area and fixed station are shown on the right, while unshaded portion is to the left. Trees are outlined in white. parking lot canopy cover, treatment scenario temperature regimes were used as input to a vehicle emissions model.

\section{Study Site}

A retail shopping-center parking lot containing shaded and unshaded portions was located in Davis, California (Figure 1), a community approximately $120 \mathrm{~km}(75 \mathrm{mi})$ northeast of San Francisco, located in California's Central Valley. Within a radius of approximately $0.3 \mathrm{~km}(0.2 \mathrm{mi})$, the shopping center was surrounded by residential neighborhoods composed primarily of single-family houses and many mature shade trees. The parking lot street frontage was approximately $180 \mathrm{~m}(590 \mathrm{ft})$ long, while the depth was approximately $48 \mathrm{~m}(157 \mathrm{ft})$. The treeshaded eastern portion of the lot was located in front of a market and comprised approximately $40 \%$ of the total parking lot area. Parking lot surface morphology (paved area, tree canopy cover) was determined from ground and aerial photo data (Elliott 1986; Wong 1996; McPherson 1998). Species identification, tree height $(\mathrm{m})$, crown height $(\mathrm{m})$, crown diameter $(\mathrm{m})$, bole height $(\mathrm{m})$, and $\mathrm{dbh}(\mathrm{cm})$ were determined using routine biometric techniques (e.g., inclinometer, dbh tape) and reported in Wong (1996). The percentage of canopy cover was determined from analysis of aerial photos taken August 18, 1995. A model CI-100 Digital Plant Canopy Imager (CID, Inc., Vancouver, Washington) was used to measure the transmission of hemispheric diffuse radiation, that is, the fraction of sky that is visible ("sky view factor"), of tree canopies located at 11 mobile transect stops in the shaded parking lot. The transmission coefficient (TC) or sky view factor is an indication of the density of canopy cover and is used to define a "shading factor" (SF) to de- 
scribe irradiance reduction by plant canopies such that $\mathrm{SF}=\left(\mathrm{SA}_{\mathrm{S}}\right)(1-\mathrm{TC}) / \mathrm{SA}_{\mathrm{T}}$, where $S A_{\mathrm{S}}$ is the surface area shaded (fractional canopy cover $\times$ total area of interest), the quantity $(1-\mathrm{TC})$ is a surface shading coefficient (where TC is the average transmission coefficient), and $\mathrm{SA}_{\mathrm{T}}$ is the total area of interest (McPherson et al. 1988). Images of individual tree canopies were taken in conjunction with mobile transect measurements, described below.

\section{Fixed Stations}

Automated weather stations were deployed to simultaneously measure climate variables (air temperature, wind speed, solar and net radiation) in an unshaded and shaded parking stall for 2 separate periods, July 22-28 and August 5-10, 1997. The July period was marked by unseasonably cool conditions attributed to El Niño/Southern Oscillation. The August period was marked by a typical warm regime. Results for the August period are discussed below. For additional climate contrast, concurrent meteorological data from a California Department of Water Resources CIMIS station, located approximately 5 $\mathrm{km}$ ( $3 \mathrm{mi}$ ) southwest of the study site, were also utilized (Snyder and Pruitt 1992; Brainard 1996). The CIMIS site is located on a University of CaliforniaDavis rural field site, within a 5.5-ha (13.6-ac) area of irrigated turfgrass. Sensors were serviced and calibrated at the manufacturer before use. Each fixed station comprised 2 tripods-one mounted with a vertical mast of fine-wire thermocouples constructed of unsheathed fine-gauge $(0.025 \mathrm{~mm}$ diameter) copper-constantan thermocouple wire at half-meter intervals $(0.5,1.0,1.5$, and $2.0 \mathrm{~m})(1.6,3.3,4.9$, and $6.6 \mathrm{ft}$ ), the other rigged with a vertical mast and crossbeam mounted with a LI-COR LI200S pyranometer (LI-COR, Inc., Lincoln, Nebraska), REBS Q*6.70 net radiometer (REBS, Inc. Seattle, Washington), and R.M. Young 03001 wind set (measurement height $1.5 \mathrm{~m}$ ) (R.M. Young Company, Traverse City, Michigan). Each instrumented tripod was connected to a Campbell Scientific CR10 datalogger and battery (Logan, Utah). Sensor readings were performed every 15 seconds and stored as 5 -minute averages. Data were downloaded daily. The shaded station was located beneath a Chinese pistache (Pistacia chinensis) with a bole height of 2.6 $\mathrm{m}(8.5 \mathrm{ft})$ and crown radius of $4.5 \mathrm{~m}(14.7 \mathrm{ft})$. Tri- pods were approximately $2.5 \mathrm{~m}(8.2 \mathrm{ft})$ from the tree trunk. A nearby Chinese elm (Ulmus parvifolia) also shaded the site. Both stations began operating at approximately noon on August 5. Hourly average air temperatures measured at the CIMIS station for the period August 5-10 were obtained for comparison with air temperatures measured at the parking lot fixed stations. Temperature difference between parking lot fixed stations (height, $z=0.5$ and $1.5 \mathrm{~m}$ ) and the CIMIS station $(z=1.5 \mathrm{~m})$ were computed for all hours. Temperature differences between shaded and unshaded sites were computed as $\Delta T(t)=T(t)_{\text {shade }}$ $T(t)_{\operatorname{sun}}$, where $T(t)$ is average temperature for the interval ending at time $t$.

\section{Mobile Transects}

Transect measurements were performed to estimate spatially averaged air temperatures in the shaded and unshaded parking lots. Transect stops were made in parking stalls (rather than travel lanes). Temperature measurements of pavement and vehicle surfaces were made using an Everest Interscience Model 130.2L Infrared Thermometer (Tucson, Arizona). In addition, a transect was performed to collect images of individual tree canopies using the CI-100. On August 6, walking transect measurements using a CORECI-type IHRT hand held air-temperature sensor (Lyon, France) were performed and consisted of stationary readings at 11 different stops on a circuit originating and ending at respective fixed climate monitoring stations. Stops on the shaded circuit were located beneath shade trees, while stops on the unshaded circuit were in full sun. Twenty-three transects were performed in the shaded lot and 22 in the unshaded lot. On August 6, numbers of vehicles parked in the shaded lot were tallied according to the relative amount of vehicle surface area in shade. Vehicles were classified as $75 \%$ to $100 \%$ shaded, $25 \%$ to $75 \%$ shaded or $0 \%$ to $25 \%$ shaded.

\section{Vehicles}

Two vehicles of the same make, model (1996 Chevrolet Corsica) and color (dark metal-flake blue) were co-located on the north side of the fixed stations. Vehicles were oriented with front ends facing southwest. Cabin air temperature and fuel-tank interior temperature were monitored concurrently with fixed station climate variables. Thermocouples composed of $1.9 \times 3.0 \mathrm{~mm}$ duplex insulated Type-T cop- 
per constantan wire were glued to the underside exterior of the fuel tank and inserted in the fuel tank via the fill line. Due to their ease of measurement, fuel tank exterior temperatures were monitored to evaluate their utility as an alternative to fuel tank interior temperature measurements. A fine-wire thermocouple was mounted in the vehicle cabin between the front driver and passenger seats at shoulder height. Cabin temperatures were monitored for future work concerning emissions associated with airconditioning use. Thermocouple leads were attached to a Campbell Scientific CR10 datalogger located in the trunk. The lead running from the fuel fill line was wrapped in laboratory film at the port to prevent fuel evaporation. Fuel tanks were approximately three-quarters full.

\section{Field Calibration}

Sensor comparisons were performed both before and after field use. Thermocouples, radiometers (model LI200S LI-COR Pyranometers and REBS Q*6.70 Net Radiometers) and anemometers (model 03001 R.M. Young Wind Set) were operated side-by-side to quantify measurement differences when instruments were co-located. Average differences or offsets between paired sensors developed from these side-by-side comparisons were small and less than manufacturerspecified errors, so that manufacturer specifications are used to define minimum differences that can be resolved. All sensors were in good agreement. Computed differences between shaded and unshaded regimes are therefore reported below without adjustment for offsets, except for the comparisons between spatially averaged (mobile transect) versus fixed-station air temperature. Because different sensors were used for mobile transect versus fixed measurements (CORECI handheld sensor versus fine-gauge thermocouple wire), it was necessary to compute offsets between the spatial average and fixedstation air temperature. Overall, temperature differences are measured to within $0.3^{\circ} \mathrm{C}\left(0.5^{\circ} \mathrm{F}\right)$.

\section{Emissions Modeling}

To calculate the air-pollutant burden posed by regional populations of motor vehicles, planners use motor-vehicle emission inventory models such as the U.S. EPA's MOBILE5 or in California, MVEI7G (ARB 1995b). These models estimate vehicle emissions during operating cycles such as startup, idling, city and highway driving, refueling, and shutdown. The models represent the contribution of various types of vehicle categories, fuels, emission controls, and travel activity to total emissions for a given day. To compute emissions such as hot soaks, starts, resting, or diurnal losses, MVEI7G uses temperature-dependent emission factors and county-specific temperature files. The temperature inputs are composited from historical meteorological data for the 10 worst air-quality days (for the pollutant of interest) from National Weather Service (NWS), California Air Resources Board (CARB), and California Department of Water Resources' California Irrigation Management Information System (CIMIS) meteorological networks (ARB 1995b). NWS surface observations are commonly located at airports, while CARB urban stations are often located at school sites, residential areas, and building rooftops. CIMIS stations are irrigated turf sites located throughout the state (Brainard 1996). A typical day's data are prepared by averaging ambient air temperature into 6 periods of varying duration (in ${ }^{\circ} \mathrm{F}$ ), which coincide with periods of vehicle activity. The "default" county temperature input therefore represents historical typical meteorological conditions for days when an air-quality standard is violated. The MVEI7G model was used to evaluate the regional impact of contrasting parking lot climate regimes on vehicle emissions for Sacramento County. Hydrocarbon emissions were computed as ROGs (reactive organic gases), which are gases designated by CARB as ozone precursors. Emissions due to hot soaks, diurnal and resting loss evaporation, as well as emissions from starts, were tabulated. Only emissions from light-duty vehicles (passenger cars and light-duty trucks) were considered. The model was run to estimate hydrocarbon and NOx emissions (tpd, tons per day) for a summer day, using the default Sacramento County temperature file and modified input files, for several cases described below.

\section{Emissions Modeling: CIMIS vs. Unshaded and Shaded Parking Lot Sites}

The first 3 model runs quantify the potential for underestimated emissions when using CIMIS tempera- 
ture inputs, rather than local-scale (e.g., parking lot) temperatures. For the first model run, input air temperatures were from a nearby CIMIS station for August 6, 1997. This day was selected because concurrent CIMIS temperatures were most similar to the default Sacramento County temperature file provided by the model. On that day, temperatures at the University of California-Davis CIMIS site averaged $0.4^{\circ} \mathrm{C}\left(0.7^{\circ} \mathrm{F}\right)$ warmer thzan the model's default temperatures for Sacramento County.

In the second case, the model was run with an air-temperature record assembled from the $0.5 \mathrm{~m}$ (1.6 ft) height unshaded parking lot site for the same day. The $0.5 \mathrm{~m}$ height was chosen to represent the height at which the bulk of a vehicle's mass is located and where ambient conditions are "felt." For the third case, the model was run with an air-temperature record assembled from the $0.5 \mathrm{~m}$ height shaded parking lot site for the same day. The second and third cases quantified emissions for typical hot summertime unshaded and shaded parking lots, where we assume most light-duty vehicle hot soak, diurnal, resting loss, and start emissions occur.

\section{Emissions Modeling: $8 \%$ vs. $25 \%$ and $50 \%$ Tree Cover}

Finally, 3 more cases were run, representing hypothetical increases in regional parking lot tree cover ( $25 \%$ and $50 \%$ canopy cover) from a base case ( $8 \%$ canopy cover). Output from the base case run quantified the emissions for the model default county temperature regime, where the countywide parking lot tree canopy cover is estimated to be $8 \%$ (Rowntree and Kerkman, 1997). The last 2 runs estimated emissions for cooler regimes resulting from increased canopy cover. For these cases, temperatures were adjusted from the base case temperatures, using proportional temperature differences between the shaded and unshaded parking lot sites.

To relate the regional impact of increases in parking lot shade to the default base case emissions, it was necessary to construct temperature regimes adjusted from the base case, to represent temperature changes resulting from an increase in canopy cover from $8 \%$ to $25 \%$, and finally, $50 \%$ (representing full compliance with local parking lot shade ordinances). To construct adjusted temperature regimes, it was assumed that the temperature difference between shaded and unshaded parking lot sites in each period was due to a difference in the percentage of canopy cover.

To estimate the temperature adjustment from the base case, the period-specific temperature rate of change (derived from the parking lot result) was multiplied by the canopy cover increase from the base case, and the product subtracted from the base case period temperature

where

$$
T a_{\mathrm{i}}=\mathrm{T} b_{\mathrm{i}}-\left(\mathrm{CCI} \times\left(\Delta \mathrm{T}_{\mathrm{i}} / \Delta \mathrm{CC}\right)\right)
$$

$T a_{i}=$

the temperature adjusted with respect to canopy cover increase for period i

$T b_{i}=$ the base case temperature for period $i$

$\mathrm{CCI}=$ canopy cover increase (e.g., 17\% for an increase from $8 \%$ to $25 \%$ canopy cover; $42 \%$ for an increase from $8 \%$ to $50 \%$ canopy cover)

$\Delta \mathrm{T}_{\mathrm{i}}=\mathrm{T}_{\text {unshaded site }}-\mathrm{T}_{\text {shaded site }}$

$\Delta C C=$ difference in canopy cover between unshaded and shaded parking lot sites (i.e., $25 \%)$

Because the existing shaded parking lot canopy cover was low (29\%) and the crown density (63\%) was sparse (shade factor $\mathrm{SF}=0.18$ ), we assume the same shade factor of 0.18 , but where canopy cover is $25 \%$ and crown density (75\%) is healthy and normal (transmission coefficient $\mathrm{TC}=0.25$ ). This "normalization" puts results in more practical terms of canopy coverage. For example, the unshaded parking lot site air temperature at $0.5 \mathrm{~m}(1.6 \mathrm{ft})$ for period 3 (representing the time interval 0900 to 1159 PST) was $86^{\circ} \mathrm{F}\left(30^{\circ} \mathrm{C}\right)$ (Table 1 ), while at the shaded site the coincident period temperature was $85^{\circ} \mathrm{F}$ $\left(29.44^{\circ} \mathrm{C}\right)$, representing a $1^{\circ} \mathrm{F}\left(0.56^{\circ} \mathrm{C}\right)$ decrease for an increase in canopy cover from $0 \%$ to $25 \%$. Similarly, for period 4 , the canopy cover contrast represents a $2^{\circ} \mathrm{F}\left(1.12^{\circ} \mathrm{C}\right)$ decrease. This method was used to compute the quantity $\left(\Delta \mathrm{T}_{i} / \Delta C C\right)$ for periods 3,4 , and 5 . No adjustments were made to the temperatures in periods 1,2 , or 6 because period temperatures were equal for shaded and unshaded sites (Table 1). For example, to compute $\mathrm{T} a$ if the canopy cover increased from $8 \%$ to $25 \%$, the temperature adjusted to $25 \%$ canopy cover for period 3 is

$$
\begin{aligned}
& \mathrm{Ta}_{3}=84^{\circ} \mathrm{F}-[(25 \%-8 \%) \times \\
& \left.\left(\left(86-85^{\circ} \mathrm{F}\right) / 25 \%\right)\right]=83^{\circ} \mathrm{F}
\end{aligned}
$$




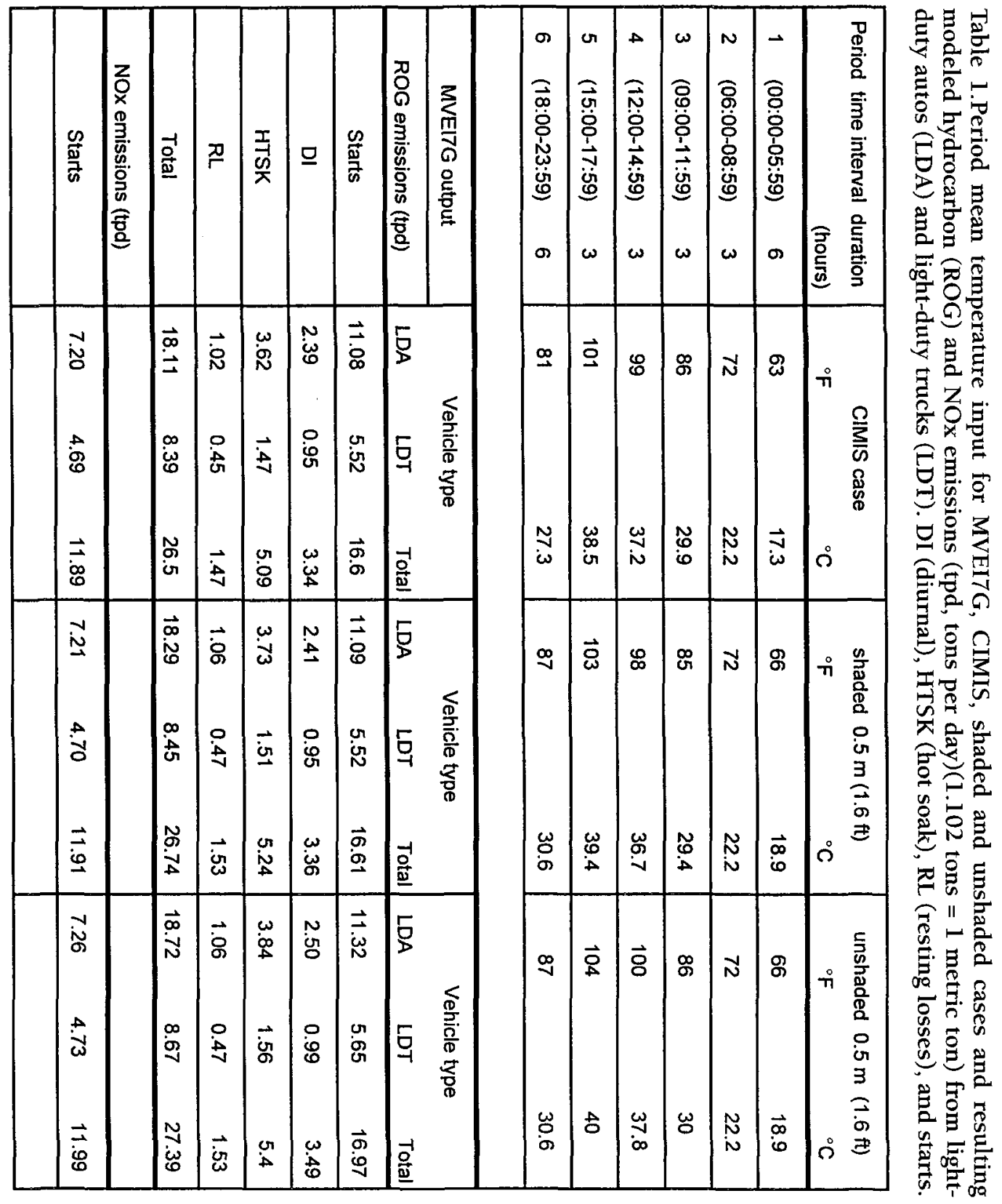




\section{RESULTS}

\section{Parking Lot Canopy Cover}

Aerial photo image analysis of the lot, taken in $\mathrm{Au}$ gust 1995, estimated shade tree canopy cover at $29 \%$ (Wong 1996; Figure 1). Shade trees were located in planter beds and individual planters among the stalls. Tree species included Chinese pistache (Pistacia chinensis), African sumac (Rhus lancea), holly oak (Quercus ilex), cork oak (Quercus suber), Siberian elm (Ulmus pumila), Chinese elm (Ulmus parvifolia), coast redwood (Sequoia sempervirens), and California fan palm (Washingtonia filifera) (Wong 1996). Forty-one percent of the shaded lot trees were Chinese elm and 34\% were Chinese pistache (Wong 1996). In August, many of the Chinese elms were defoliating due to drought stress. With the exception of the northern street frontage, trees were absent from the western half of the shopping complex. From 11 images (corresponding to individual mobile transect stops), transmission coefficients for hemispherical diffuse radiation ranged from 0.1 to 0.77 , averaging 0.37 , where increasing transmission coefficients indicate decreasing canopy density (e.g., less shade). The parking lot shading factor (SF) was equal to 0.18 (where $S A_{S}=0.29 \times 4,973 \mathrm{~m}^{2}$ lot area, the quantity $(1-\mathrm{TC})=(1-0.37)=0.63$ and $S A_{\mathrm{T}}=$ $4,973 \mathrm{~m}^{2}$ ). These measures confirmed visual observation that canopy density was sparse and variable. Climate differences between shaded and unshaded parking lots inferred from measurements discussed below are therefore conservative.

\section{Synoptic Conditions}

Skies were cloud-free August 5-9, although smoke from biomass burning and cirrus clouds were present on August 6. Scattered clouds were present on August 10 (Figure 2a). During the period August 5-7, a stationary ridge of high pressure on the U.S. west coast prevented the development of afternoon sea breezes in the Sacramento region of the Central Valley. During the period August 5-10, daytime temperatures were warm (Figure 2b). Maximum daytime temperatures occurred on August 7 , exceeding $41^{\circ} \mathrm{C}\left(105.8^{\circ} \mathrm{F}\right)$ at the unshaded parking lot site. As a result of a southward migration of the high-pressure ridge, an afternoon sea-breeze regime returned by August 8 , resulting in cooler daytime highs August 8-10. Therefore, August 5-7 was defined as a warm period, with
August 8 a transition to a cooler regime for August 9 and 10. Daytime wind speeds for the warm period August 5-7 were light and variable. Wind speeds were greatest during the afternoon, averaging $0.5 \mathrm{~m} / \mathrm{s}$ $(1.1 \mathrm{mi} / \mathrm{hr}$ ) from a southerly direction. Afternoon wind speeds August 8-10 exceeded $1 \mathrm{~m} / \mathrm{s}$ ( $2.2 \mathrm{mi} / \mathrm{hr}$; Figure $2 \mathrm{c}$ ) and came from the south and west.

\section{Air Temperature: CIMIS vs. Parking Lot}

The shaded parking lot site was warmer than the CIMIS site for late afternoon through the early morning hours (Figure $3 \mathrm{a}$ ) and cooler than the CIMIS site for only a few hours, from late morning to early afternoon. During the August 5-7 warm period, the shaded site was approximately $0.5^{\circ} \mathrm{C}$ $\left(0.9^{\circ} \mathrm{F}\right)$ cooler than CIMIS from the hour ending at 0800 PST to afternoon (1500 PST). Temperatures at the shaded site began to exceed CIMIS during the hours from approximately 1500 to 1900 PST, increasing to over $2^{\circ} \mathrm{C}\left(3.6^{\circ} \mathrm{F}\right)$ warmer than CIMIS during nighttime and predawn hours. The unshaded parking lot site was warmer than the CIMIS site for almost all hours of the day, for the whole period of August 5-10.

\section{Parking Lot Air Temperature}

During the warm period August 5-7, afternoon maximum temperatures (hourly average, all heights) at the unshaded site exceeded $40^{\circ} \mathrm{C}\left(104^{\circ} \mathrm{F}\right)$, while maximums at the shaded site were approximately $1^{\circ} \mathrm{C}\left(1.8^{\circ} \mathrm{F}\right)$ less. Early-morning lows at the unshaded site (hourly average, all heights) August 6-8 during the hour 0400 to 0500 PST were approximately $20^{\circ} \mathrm{C}\left(68^{\circ} \mathrm{F}\right.$; Figure $\left.2 \mathrm{~b}\right)$. The daytime maximum temperature on August 8 at the unshaded site was approximately $37^{\circ} \mathrm{C}$ and decreased on successive days to approximately $29^{\circ} \mathrm{C}$ and $26^{\circ} \mathrm{C}\left(84.2^{\circ} \mathrm{F}\right.$ and $78.8^{\circ} \mathrm{F}$ ). Early-morning lows on August 9 and 10 were approximately $16^{\circ} \mathrm{C}\left(60.8^{\circ} \mathrm{F}\right)$. Temperature differences between the shaded and unshaded site were less pronounced during the cooling trend of August $8-10$, averaging $-0.6^{\circ} \mathrm{C}\left(-1.08^{\circ} \mathrm{F}\right)$.

Air-temperature differences between the shaded and unshaded stations also varied with measurement height. The greatest air-temperature differences between the shaded and unshaded sites were observed at the $0.5 \mathrm{~m}(1.6 \mathrm{ft})$ measurement height (e.g., in proximity to warm paved surfaces). During the Au- 
(a)

(b)

(c)
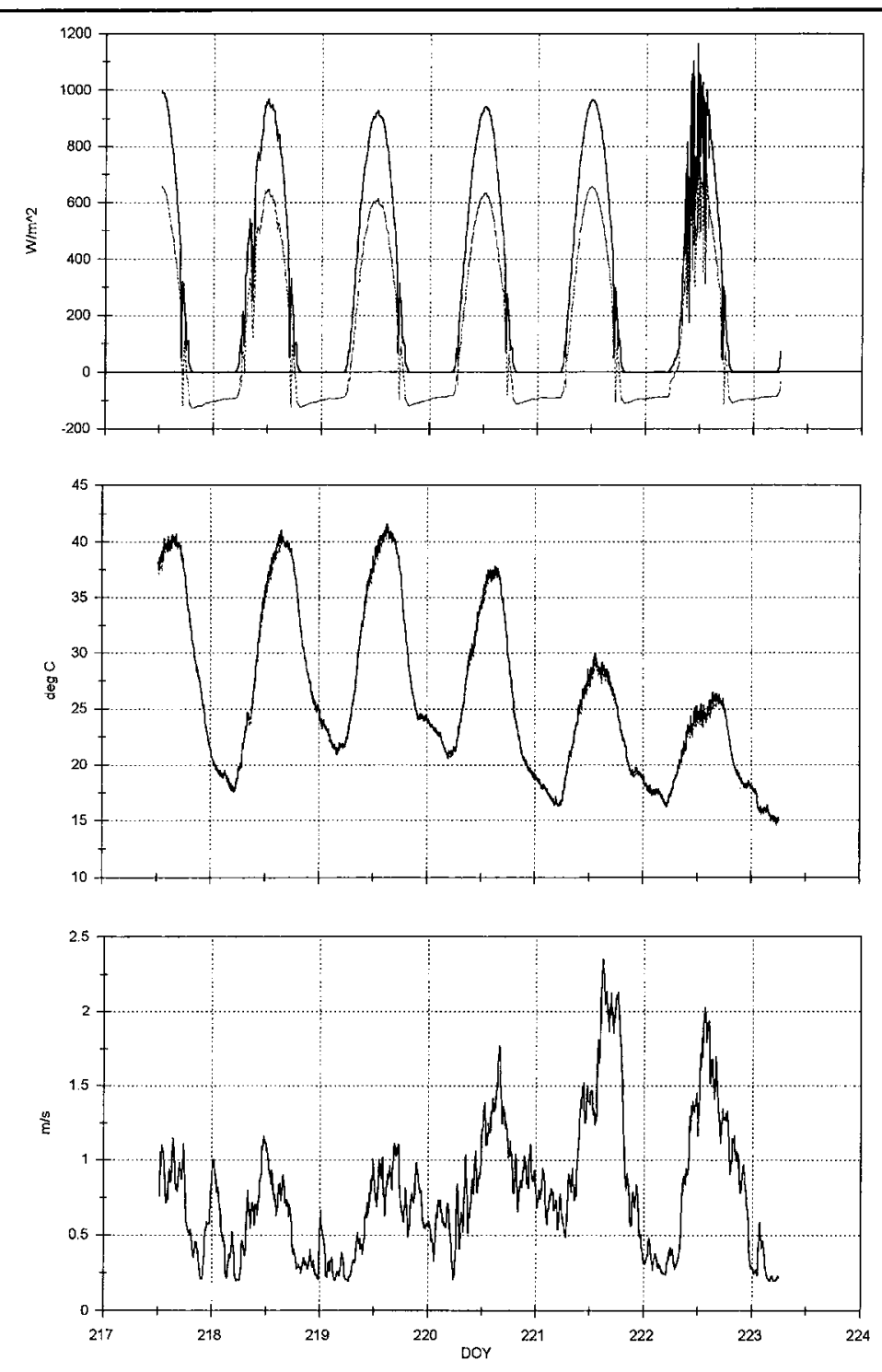

Figure 2. Overview of measured climate variables, beginning noon August 5 (DOY 217) through early morning August 11 (DOY 223) 1997. Unshaded parking lot site. (a) radiation (- solar; $\cdots$ net); (b) air temperature $\left({ }^{\circ} \mathrm{C}\right)$; (c) wind speed $(\mathrm{m} / \mathrm{s})$.

gust 5-7 warm period, afternoon air temperatures during the hours from 1200 to 1400 PST measured at $0.5 \mathrm{~m}$ in the shaded lot site were approximately $1.3^{\circ} \mathrm{C}\left(2.3^{\circ} \mathrm{F}\right)$ cooler than the unshaded site (Figure 3b). The surface temperature difference between shaded and unshaded pavement was larger than the measured air-temperature differences. For example, on August 6 afternoon infrared surface temperatures of asphalt at the unshaded site exceeded $60^{\circ} \mathrm{C}$ $\left(140^{\circ} \mathrm{F}\right)$, while temperatures at the shaded site were slightly less than $40^{\circ} \mathrm{C}\left(104^{\circ} \mathrm{F}\right)$. With increasing height, afternoon air-temperature differences between the shaded and unshaded site diminished to slightly less than $-1{ }^{\circ} \mathrm{C}$ $\left(-1.8^{\circ} \mathrm{F}\right.$; Figure $\left.3 \mathrm{~b}\right)$.

The difference between the spatial average and the fixed station air temperature averaged $+0.26^{\circ} \mathrm{C}(\sigma=$ $0.30^{\circ} \mathrm{C}$ ) for the shaded lot and $-0.003^{\circ} \mathrm{C}\left(\sigma=0.33^{\circ} \mathrm{C}\right)$ for the unshaded lot, suggesting that fixed station measurements were representative of parking stall temperatures in shaded and unshaded lots.

\section{Shaded Lot Occupancy}

Parking lot occupancy and vehicle shading were tallied during mobile transects performed on August 6 (although not tallied, the unshaded parking lot had few parked vehicles for the same day). A user preference for shaded parking stalls seemed evident during 1 of 2 periods of minimum occupancy (approximately 30\%), at 0817 and 1822 PST. During the morning observation, temperatures were mild (approximately $23^{\circ} \mathrm{C}\left[73.4^{\circ} \mathrm{F}\right]$ ), and the percentages of vehicles exhibiting $75 \%$ to $100 \%, 25 \%$ to $75 \%$, and $<25 \%$ shading were $25 \%, 40 \%$, and $35 \%$, respectively. During the afternoon observation, temperatures were warmer (approximately $38^{\circ} \mathrm{C}\left[100.3^{\circ} \mathrm{F}\right]$ ), and the distribution changed to $68 \%$ of the vehicles in $75 \%$ to $100 \%$ shade, $11 \%$ of the vehicles in $25 \%$ to $75 \%$ shade, and $21 \%$ in 
$<25 \%$ shade. For all observations, over half (approximately $60 \%$ ) of the counted vehicles were shaded at greater than $25 \%$.

\section{Vehicle Temperatures}

Maximum fuel-tank temperatures during the August 5-7 warm period for the unshaded vehicle averaged $41.6^{\circ} \mathrm{C}\left(106.9^{\circ} \mathrm{F}\right)$ for the fuel-tank interior. Maximum fuel-tank interior temperatures August 5-7 for the shaded vehicle averaged $38.6^{\circ} \mathrm{C}\left(101.5^{\circ} \mathrm{F}\right)$, ranging from $2.1^{\circ} \mathrm{C}$ to $3.7^{\circ} \mathrm{C}\left(3.8^{\circ} \mathrm{F}\right.$ to $\left.6.7^{\circ} \mathrm{F}\right)$ less than those for the unshaded vehicle. When averaged with respect to hour of the day over the August 57 warm period, shaded fuel-tank interior temperatures were coolest during the hours from 1700 to 2000 PST by approximately $3.1^{\circ} \mathrm{C}\left(5.6^{\circ} \mathrm{F}\right)$, compared to the unshaded vehicle (Figure 3c). Cabin temperatures were markedly different between shaded and unshaded vehicles. During the August 5-8 period, cabin temperature exceeded $65^{\circ} \mathrm{C}\left(149^{\circ} \mathrm{F}\right)$ in the unshaded vehicle, while the shaded vehicle maximum temperatures were less than $50^{\circ} \mathrm{C}$ $\left(122^{\circ} \mathrm{F}\right)$. When averaged with respect to hour of the day during the period August 5-7, cabin temperatures in the shaded vehicle were cooler by approximately $26.2^{\circ} \mathrm{C}\left(47.2^{\circ} \mathrm{F}\right)$ during the hours from 1300 to 1600 PST. During the entire period August 5-10, the shaded vehicle cabin temperature during the hours from 1200 to 1700 PST was approximately $25^{\circ} \mathrm{C}\left(45^{\circ} \mathrm{F}\right)$ cooler than the unshaded vehicle. shaded - unshaded.
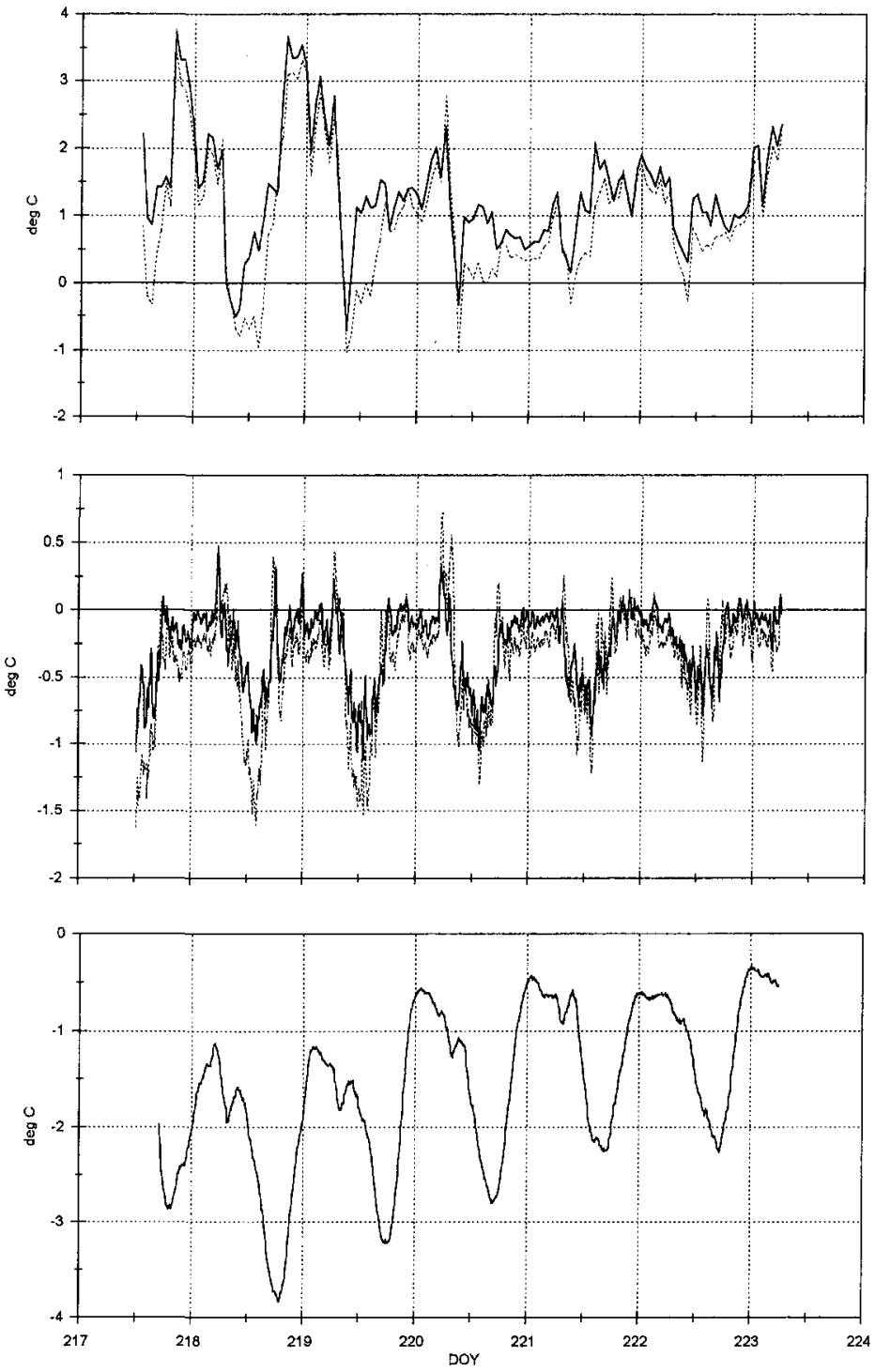

Figure 3. Temperature differences, beginning noon August 5 (DOY 217) through early morning August 11 (DOY 223). (a) parking lot 0.5-m air - CIMIS difference (- shaded; $\cdots$ unshaded); (b) parking lot air-temperature difference: shaded-unshaded (- $1.5 \mathrm{~m} ; \cdots 0.5 \mathrm{~m})$; (c) fuel-tank interior difference:

\section{Radiation}

Midday maximum solar radiation throughout the period August 5-10 exceeded $900 \mathrm{~W} / \mathrm{m}^{2}$ at the unshaded site (Figure 2a). Average midday (for 1200 to 1300 PST) solar radiation at the unshaded site for the same period was approximately $945 \mathrm{~W} / \mathrm{m}^{2}$. By contrast, incoming solar radiation at the shaded site averaged $185 \mathrm{~W} / \mathrm{m}^{2}$ during the hour from noon to 
13:00 PST, a reduction of nearly $80 \%$. The measured reduction of incoming solar radiation by the tree canopy is approximate, because the response of the pyranometer silicon photo diode sensor is less than ideal within plant canopies, where the spectral environment is different from environments in full sun (LI-COR 1991).

\section{Discussion of Microclimate Differences}

Observed reductions in solar radiation at the shaded parking lot site and air-temperature reductions near the paved surface suggest that air-temperature reduction is due in large part to irradiance attenuation attributable to tree shade. Observed temperature differences between shaded and unshaded vehicle fuel tanks, which are larger in magnitude than air-temperature differences, suggest that irradiance also has a significant effect on vehicle temperature. Based on observed daytime parking lot occupancy, users appeared to select shaded parking stalls over stalls with less shade. This implies that given sufficient canopy cover, differential use of shaded or partially shaded stalls may influence total emissions. Overall, temperature differences during the hottest days suggest that at this very modest level of shading, trees exerted an air-temperature reduction of approximately $1^{\circ} \mathrm{C}$ to $2^{\circ} \mathrm{C}\left(1.8^{\circ} \mathrm{F}\right.$ to $\left.3.6^{\circ} \mathrm{F}\right)$, compared to unshaded lots. The shaded fuel tank was $2^{\circ} \mathrm{C}$ to $4^{\circ} \mathrm{C}\left(3.6^{\circ} \mathrm{F}\right.$ to $7.2^{\circ} \mathrm{F}$ ) cooler than the unshaded, which suggests that irradiance reduction contributes another $1^{\circ} \mathrm{C}$ to $2^{\circ} \mathrm{C}$ reduction in fuel-tank temperature. The influence of paving surface is also observed with respect to the turfgrass CIMIS site, where air temperatures are on the order of $1^{\circ} \mathrm{C}$ to $2^{\circ} \mathrm{C}$ cooler than either parking lot site. The interaction of surface characteristics and canopy cover are consistent with previous paired microclimate measurements performed in Davis and Sacramento, California. For example, Myrup et al. (1993) reported midday air temperatures at an unshaded suburban development approximately $2.5^{\circ} \mathrm{C}\left(4.5^{\circ} \mathrm{F}\right)$ warmer than a nearby open rural site, while temperatures at an older, shaded residential neighborhood were $2.5^{\circ} \mathrm{C}$ cooler than the open site. Nighttime air temperatures were also warmer by $1^{\circ} \mathrm{C}$ at the unshaded suburban site compared to the control site. A field study in Sacramento reported August daytime air temperatures at shaded urban sites ranging from $0.3^{\circ} \mathrm{C}$ to $2.9^{\circ} \mathrm{C}$ $\left(0.5^{\circ} \mathrm{F}\right.$ to $\left.5.2^{\circ} \mathrm{F}\right)$ cooler than unshaded locations (Myrup and Morgan 1972). Imamura et al. (1992) reported that Sacramento's tree cover exerted cooling rates of approximately $1^{\circ} \mathrm{C}$ per hour. Because of the relatively low percentage of canopy cover of the parking lot, climate contrasts between the shaded parking lot site and the CIMIS station reported here are conservative,

\section{Emissions Modeling: CIMIS vs. Unshaded And Shaded Parking Lot Sites}

Air-temperature inputs used to model the CIMIS, shaded and unshaded parking lot regimes are listed in Table 1, together with modeled vehicle emissions from the 3 cases. Parking lot temperature regimes were warmer than the CIMIS site during Periods 1 , 5 , and 6 . The unshaded parking lot temperature regime, as well as the shaded regime, were both warmer overall than the CIMIS case, resulting in greater emissions. Total ROG emissions for the parking lot cases are 3\% (unshaded) and 1\% (shaded) greater than the CIMIS case, suggesting that CIMIStype temperature regimes may underestimate emissions. Emissions modeled with parking lot temperatures are between $4 \%$ (shaded) and $7 \%$ (unshaded) greater than emissions modeled with the default or "base case" county temperature file provided by the model (next section).

Differences in ROG emissions between unshaded and shaded parking lot cases are small (Table 1). For example, diurnal ROG emissions for the shaded parking lot case (3.36 tpd) are approximately $3.7 \%$ less than diurnal ROGs for the unshaded case (3.49 tpd). The total ROG reduction between shaded and unshaded parking lot cases is a modest $2 \%$.

\section{Emissions Modeling: $8 \%$ vs. $25 \%$ and $50 \%$ Tree Cover}

Input temperature regimes and model results are summarized in Table 2. ROG diurnal emissions for the $50 \%$ canopy-cover case were $7.5 \%$ less than the base case ( $8 \%$ canopy cover), while hot soaks were $4 \%$ less than the base case. Although ROG emissions from starts with $50 \%$ canopy cover were reduced by $2.5 \%$ from the base case, the tonnage reduction $(16.46-16.04=0.42 \mathrm{tpd})$ was as great as the reductions from diurnal and hot soak emissions combined (0.41). ROG emissions for the 50\% canopy cover 
case were 0.85 tpd less than the $8 \%$ canopy cover base case, representing a reduction of $3.3 \%$. For the $50 \%$ canopy-cover case, NOx reduction was $0.1 \mathrm{tpd}$. The starts, evaporative diurnal, hot soak, and resting loss ROG emissions are however only a part of the total ROG emissions, which include "running exhaust" and "running losses." For the 50\% canopy cover case, total ROG emissions are 29.43 tpd for light-duty autos and 13.43 for light-duty trucks (data not shown). Taken together, the 0.85 tpd ROG reduction represents a $2 \%$ reduction of the overall light-duty vehicle ROG emissions. Similarly, the starts NOx reduction represents a small portion $(0.2 \%)$ of the total light-duty vehicle NOx emissions.

\section{LIMITATIONS AND CONCLUSIONS}

Paired observations show that parking lot temperature regimes are warmer than those over irrigated turf. Even sparse tree canopy exerted a cooling effect on both parking lot climate and vehicle temperature. Based on the observations, temperature inputs composited from typical meteorological networks may, by not accounting for urban heat-island effects on temperature, cause vehicle emission inventory models to underpredict ROG diurnal, resting loss, hot soak, and starts emissions. Motor-vehicle emission model scenarios indicate that increasing parking lot canopy cover from $8 \%$ to $50 \%$ would reduce Sacramento County's light-duty vehicle ROG evaporative emissions by $2 \%(0.85 \mathrm{tpd})$ and NOx start emissions by less than $1 \%(0.1 \mathrm{tpd})$. The projected motor-vehicle ROG percentage reductions in Sacramento were in reasonable agreement with spatially resolved, urban heat-island model results for the Los Angeles basin, where mobile source emissions were reduced by $1.5 \%$ (Taha 1997). Though modest, the projected ROG reductions $(0.85 \mathrm{tpd})$ are equivalent to projected hydrocarbon emission reductions for existing air-quality management district control measures for graphic arts, ethylene oxide sterilizers, alternative fuel stations, and waste burning (totaling 0.89 tpd; SMAQMD 1994). Projected NOx emission reductions $(0.1 \mathrm{tpd})$ were equivalent to reductions projected from the district's light-duty vehicle scrappage program (0.1 tpd; SMAQMD 1994).

The above MVEI7G modeling scenarios were based on conservative air-temperature reductions and did not account for irradiance effects on vehicle temperature. By analogy with the "equivalent black- body temperature" concept used in biophysical energy budget studies, an "effective" air temperature could be developed. An effective air-temperature input to the MVEI7G model, incorporating both airtemperature and irradiance reduction resulting from tree canopy cover, would presumably predict greater emission reductions resulting from shade. At the same time, an effective air temperature may also better predict emissions for unshaded conditions in which both air temperatures and irradiance are high. In addition, because a large fraction of the modeled ROG emission reductions were from starts, reduced cabin air-conditioning use may also realize additional emission reductions.

To determine how microclimate, vehicle temperature, and emissions scale with tree canopy cover, observations need to be performed for a range of conditions (e.g., parking lot size, paving surface, tree canopy cover and density). A corollary to this issue is a need to develop a parking lot taxonomy that accounts for lot size, patterns of use, occupancy by vehicle type, and landscape characteristics. A parking lot taxonomy will also inform benefit-cost analyses for the development of effective parking lot shade treatments and for estimating potential regional-scale vehicle emission reductions. Cost-benefit analyses of parking lot aforestation programs should consider potential biogenic hydrocarbon emissions by various tree species, which may offset evaporative emission reductions from vehicles.

Comprehensive cost-benefit analyses of parking lot planting programs should consider the stream of costs associated with site preparation, tree planting, maintenance, hydrocarbon emissions from landscape equipment and trees, water use, and administration. Other concerns include potential conflicts with lighting, visibility, signage, security, and vehicle damage due to tree limbs and bird and tree litter. Benefits to consider include avoided vehicle emissions (which will change with the introduction of new low-emission technologies into the vehicle fleet), potential prolonged pavement life due to shade, mitigation of urban heat islands, reduced human exposure to UV radiation due to canopy interception, air-pollutant uptake by tree canopies, and mitigation of urban stormwater runoff. Additionally, the effects of tree cover on business sales, vacancy rates, space leasing rates, and other indicators of economic activity need to be addressed. 


\begin{tabular}{|c|c|c|c|c|c|c|c|c|c|c|c|c|c|c|c|c|}
\hline$\frac{\mathscr{\rho}}{\frac{\partial}{7}}$ & 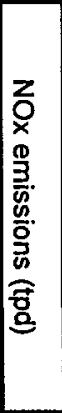 & 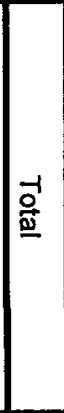 & $\underline{\underline{\underline{T}}}$ & $\begin{array}{l}\frac{I}{A} \\
\frac{\infty}{X}\end{array}$ & 므 & $\stackrel{\infty}{\frac{\infty}{m}}$ & 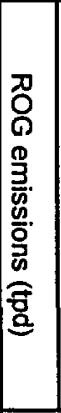 & 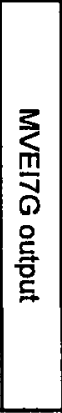 & 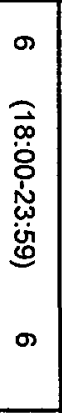 & 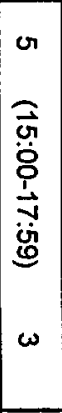 & 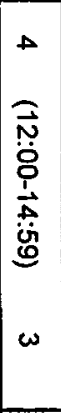 & 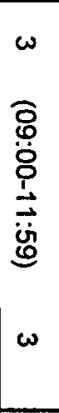 & 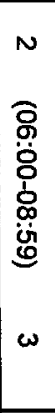 & 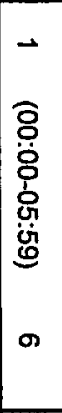 & 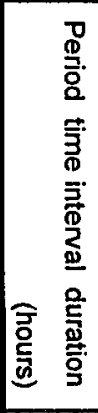 & 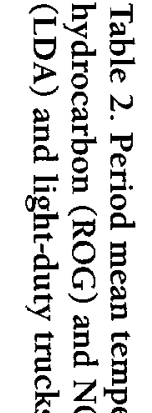 \\
\hline $\overrightarrow{\vec{\infty}}$ & & 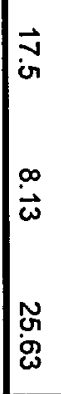 & 总 & $\underset{⿱ 中}{*}$ & $\stackrel{N}{v}$ & $\begin{array}{l}\vec{\sigma} \\
\vec{\sigma}\end{array}$ & 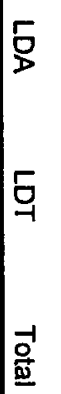 & 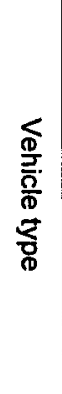 & $\underset{\sim}{\boldsymbol{\sigma}}$ & $\underset{\infty}{\omega}$ & $\underset{\rightarrow}{\stackrel{\omega}{\sim}}$ & $\begin{array}{l}\mathbb{\infty} \\
0 \\
0\end{array}$ & $\begin{array}{l}N \\
\stackrel{N}{\sigma} \\
0\end{array}$ & $\tilde{O}$ & 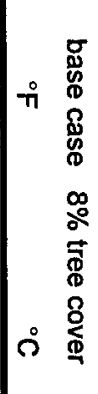 & 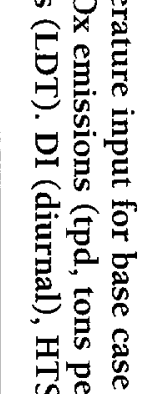 \\
\hline$\stackrel{\leftrightarrow}{\circ}$ & & 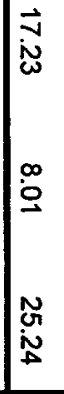 & E & 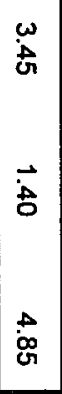 & హั & $\vec{\sigma}$ & 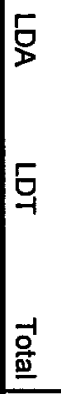 & 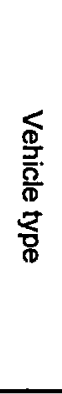 & $\underset{\sim}{\boldsymbol{\sigma}}$ & 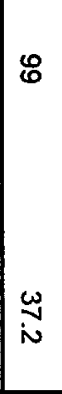 & $\begin{array}{l}w \\
\omega \\
\sigma\end{array}$ & $\underset{\mathbf{\omega}}{\mathbf{\omega}}$ & $\begin{array}{l}N \\
\text { No } \\
0\end{array}$ & $\mathscr{\infty}$ & 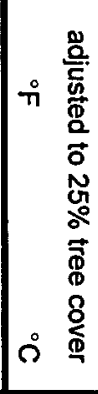 & 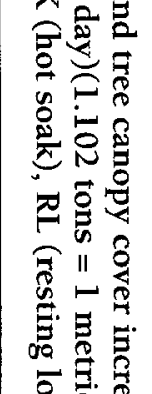 \\
\hline$\stackrel{+}{8}$ & & 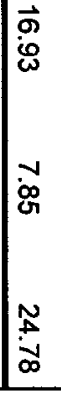 & $\overrightarrow{\text { जी }}$ & $\overrightarrow{\tilde{\omega}}$ & $\stackrel{\circ}{\omega}$ & $\begin{array}{l}\vec{\sigma} \\
\stackrel{\circ}{+}\end{array}$ & 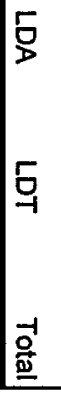 & 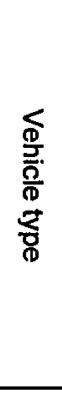 & $\underset{\sim}{\sim}$ & $\stackrel{\omega}{\boldsymbol{\omega}}$ & $\underset{+}{\stackrel{\omega}{\Delta}}$ & $\underset{\infty}{N}$ & $\begin{array}{l}N \\
\text { No } \\
\end{array}$ & ஜ & 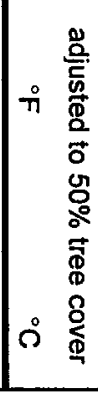 & 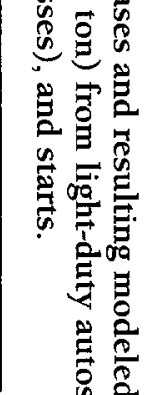 \\
\hline
\end{tabular}




\section{LITERATURE CITED}

Air Resources Board. 1995a. Emission Inventory. Technical Support Division, Sacramento, CA.

Air Resources Board. 1995b. Methodology for Estimating Emissions from On-Road Motor Vehicles. Volume 1: Introduction and Overview. Technical Support Division, Mobile Source Emission Inventory Branch, Sacramento, CA.

Asaeda, T., V.T. Ca, and A. Wake. 1996. Heat storage of pavement and its effect on the lower atmosphere. Atmos. Environ.: Urban Atmos. 30(3):413-427.

Beatty, R.A. 1989. Planting guidelines for heat island mitigation and energy conservation. In Garbesi, K.. et al. (Eds.). Controlling Summer Heat Islands. Proceedings of the Workshop on Saving Energy and Reducing Atmospheric Pollution by Controlling Summer Heat Islands. February 23-24, 1989, Lawrence Berkeley Laboratory. University of California, Berkeley, Ca.

Brainard, L. 1996. CIMIS Urban Resource Book. California Department of Water Resources, Sacramento, CA. 59 pp.

Cardelino, C.A., and W.L. Chameides. 1990. Natural hydrocarbons, urbanization and urban ozone. J. Geophys. Res. 95:13971-13979.

Elliott, K.E. 1986. Tree Shade in Urban Parking Facilities: An Evaluation of Parking Patterns and the Davis Mandatory Shade Ordinance. Thesis. Department of Geography, University of California, Berkeley, CA. 136 pp.

Grimmond, C.S.B., T.R. Oke, and H.A. Cleugh. 1993. The role of "rural" in comparisons of observed suburbanrural flux differences. In Exchange Processes at the Land Surface for a Range of Space and Time Scales. Proceedings of the Yokohama Symposium, July 1993.

Hahn, H.H., and R. Pfeifer. 1994. The contribution of parked vehicle emissions to the pollution of urban run-off. Sci.Total Environ. 146/147:525-533.

Huang, J., H. Akbari, H. Taha, and A. Rosenfeld. 1987. The potential of vegetation in reducing summer cooling loads in residential buildings. J. Clim. Appl. Meteorol. 26:1103-1106.

Imamura, I.R., T. Nishizawa, and R.D. Bornstein. 1992. The Sacramento urban summer heat island study. 2nd Tohwa University International Symposium, CUTEST92. September 7-10, 1992, Fukuoka, Japan.

ICLEI. 1997. U.S. Communities Acting to Protect the Climate. International Council for Local Environmental Initiatives, Berkeley, California.

Lee, R. 1978. Forest Microclimatology. Columbia University Press, New York, NY.

LI-COR, Inc. 1991. LI-COR Terrestrial Radiation Sensors, Type SZ Instruction Manual. Publication No. 8609-60. Lincoln, Nebraska.
McPherson, E.G. 1998. Structure and sustainability of Sacramento's urban forest. J. Arboric 24(4):174-190.

McPherson, E.G., L.P. Herrington, and G.M. Heisler. 1988. Impacts of vegetation on residential heating and cooling. Energy Build. 12:41-51.

Myrup, L.O., C.E. McGinn, and R.G. Flocchini. 1993. An analysis of microclimatic variation in a suburban environment. Atmos. Environ. 27B:129-156.

Myrup, L.O., and D.L. Morgan. 1972. Numerical Model of the Urban Atmosphere, Vol. 1: The City-Surface Interface. Contributions in Atmospheric Science No. 4. University of California, Davis, CA.

National Arbor Day Foundation. 1995. Trees and Parking Lots. Fazio, J.R. (Ed.). Tree City USA Bulletin No. 24. Nebraska City, Nebraska. 8 pp.

Oke, T.R. 1987. Boundary Layer Climates. Methuen, New York, NY.

Rowntree, R., and E. Kerkman. 1997. Urban forest canopy cover in California: analysis of 21 cities and towns. Unpublished technical report. USDA Forest Service, Pacific Southwest Research Station, Albany, CA.

Sacramento Metropolitan Air Quality Management District. 1994. Post-1996 Rate of Progress Plan for Ozone. $72 \mathrm{pp}$.

Simpson, J.R., D.G. Levitt, C.S.B. Grimmond, E.G. McPherson, and R.A. Rowntree. 1994. Effects of vegetative cover on climate, local scale evaporation and air conditioning energy use in urban southern California, pp 345-348. In 11th Conference on Biometeorology and Aerobiology, March 7-11, 1994, San Diego, CA, American Meteorological Society.

Snyder, R.L., and W.O. Pruitt. 1992. Evapotranspiration data management in California, pp 128-133. In Irrigation \& Drainage Session Proceedings/Water Forum '92, August 2-6, 1992. Baltimore, MD. American Society of Civil Engineers.

Taha, H., H. Akbari, and A. Rosenfeld. 1991. Heat island and oasis effects of vegetative canopies: micro meteorological field measurements. Theor. Appl. Climatol. 44:123-138.

Taha, H. 1996. Modeling impacts of increased urban vegetation on ozone air quality in the South Coast Air Basin. Atmos. Environ. 30(20):3423-3430.

Taha, H. 1997. Modeling the impacts of large-scale albedo changes on ozone air quality in the South Coast Air Basin. Atmos. Environ. 31(11):1667-1676.

Wong, T.-W. 1996. Parking Lot Shade Study: A Critical Examination of Davis Parking Lot Tree Shade. Thesis. Department of Environmental Design, University of California, Davis. 
Acknowledgements. The authors thank Jeff Long and Michael Benjamin (CARB) and Richard Snyder (UC Cooperative Extension) for their helpful comments on design of the field program; Patrick Chua, Victoria Fan, and Sumer Seiki for their help with field data collection; Chris Hostetler (Albertson's, Inc.) for site permission; Edwin Civerolo (USDA Crops Pathology) and Jason Webber for assistance with equipment transport. This work was supported in part through a John Z. Duling Grant (International Society of Arboriculture Research Trust) and the USDA Forest Service Asian Pacific American Recruitment Initiative. Use of trade or firm names in this paper does not imply endorsement by the U.S. Department of Agriculture of any product or service.

\section{USDA Forest Service}

Pacific Southwest Research Station

Western Center for Urban Forest Research and Education

clo Department of Environmental Horticulture

University of California

Davis, CA 95616

Corresponding author, Klaus Scott; present affiliation, California Air Resources Board, P.O. Box 2815, Sacramento, CA 95812.
Résumé. Une étude pilote a été menée pour mesurer la différence de microclimat dans une aire de stationnement résultant de la présence ou de l'absence de couvert arboré. Les données mesurées de microclimat prises à partir des régimes contrastant d'ombrage ont ensuite été utilisées comme entrées dans un modèle d'émission des véhicules moteur. Les résultats du modèle ont ensuite été utilisées pour estimer le potentiel régional d'accroissement du couvert arboré dans les aires de stationnement pour réduire les émissions d'hydrocarbures et d'oxydes nitreux (NOx) des moteurs de véhicules.

Zusammenfassung. In einer Pilotstudie wurden die Differenzen im Mikroklima auf einem Parkplatz mit und ohne schattenspendende Bäume gemessen. Die gemessenen Daten aus den unterschiedlichen Schattenbedingungen wurden dann als Input für ein Autoabgasemissionsmodell benutzt. Die Resultate aus diesem Modell wurden dann verwendet, um das Potential von regionalen Zunahmen an Baumbedeckung von Parkplätzen zur Reduzierung von Autoabgasemissionen zu bewerten.

Resumen. Un estudio piloto fue llevado a cabo para medir la diferencia en el microclima de un estacionamiento debido a la presencia o ausencia de la sombra por cobertura arbórea. Los datos del microclima, medidos de los regimenes contrastantes de sombra, fueron usados como entrada en un modelo de emisiones de motores vehiculares. Los resultados del modelo fueron usados para estimar el potencial para reducir las emisiones de motores vehiculares de hidrocarbono y oxido de nitrógeno (NOx) al incrementar lotes de estacionamientos con cubierta arbórea de manera regional. 